Jurnal Basicedu Volume 4 Nomor 2 April 2020 Hal. 476- 483

JURNAL BASICEDU

Research \& Learning in Elementary Education

https://jbasic.org/index.php/basicedu

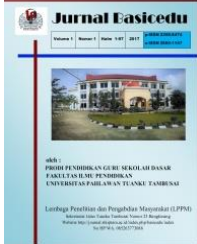

\title{
PENGEMBANGAN BAHAN AJAR TEMATIK TERPADU DENGAN STRATEGI QUESTION STUDENT HAVE DI SEKOLAH DASAR
}

\author{
Weriyanti $^{1}$, Firman $^{2}$,Taufina ${ }^{3,}$ Ahmad Zikri ${ }^{4}$ \\ Universitas Negeri Padang, Sumatera Barat, Indonesia ${ }^{1,2,3,4}$

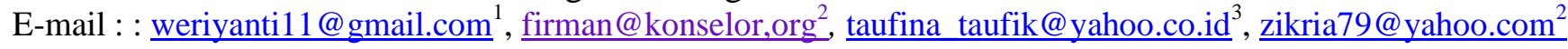

\begin{abstract}
Abstrak
Penelitian ini bertujuan untuk menghasilkan bahan ajar tematik dengan strategi Question Student Have untuk pendidik kelas IV yang valid, praktis, dan efektif. Penelitian ini menggunakan penelitian pengembangan berdasarkan model 4D (Define, Design, Develop dan Disseminate). Kevalidan dilhat dari segi isi, bahasa, penyajian, kegrafikaan dan RPP, keseluruhan 3,54 dengan kategori sangat valid. Pratikalitas bahan ajar dilihat dari respon pendidik dengan ratarata $90 \%$ respon peserta didik $90 \%$. Dapat disimpulkan bahwa bahan ajar tematik menggunakan strategi Qustion Student Have yang dikembangkan layak digunakan di kelas IV SD.
\end{abstract}

Kata Kunci: Bahan Ajar, Pembelajaran Tematik, Strategi Question Student Have

\begin{abstract}
This study aims to produce thematic teaching materials with the Question Student Have strategy for class IV educators that are valid, practical, and effective. This study uses development research based on the 4D model (Define, Design, Develop and Disseminate). Validity is seen in terms of content, language, presentation, graphic and lesson plans, overall 3.54 with a very valid category. The practicality of teaching materials is seen from the responses of educators with an average of $90 \%$ of students' responses by $90 \%$. It can be concluded that the thematic teaching materials using the Qustion Student Have strategy developed are suitable for use in grade IV elementary school.
\end{abstract}

Keywords: Teaching Material, Thematic Learning, Question Student Have Strategy

@ Jurnal Basicedu 2020

$\triangle$ Corresponding author:

Address : Air Tawar Padang

Email : weri11@gmail.com

ISSN 2580-3735 (Media Cetak)

Phone : 089531307164

ISSN 2580-1147 (Media Online) 
477 Pengembangan bahan ajar tematik terpadu dengan strategi question student have di sekolah dasarWeriyanti, Firman, Taufina, Ahmad Zikri

\section{PENDAHULUAN}

Pemerintah selalu berupaya untuk meningkatkan kualitas pendidikan di Indonesia sesuai dengan kebutuhan dan perkembangan zaman. Berbagai upaya telah dilakukan pemerintah dalam meningkatkan kualitas pendidikan di Indonesia misalnya peningkatan aggaran pendidikan, peningkatan mutu guru dan kepala sekolah, memperbaiki fasilitas sekolah, adanya pengembangan kurikulum, serta adanya pergantian kurikulum yang disesuaikan dengan keadaan zaman. Pendidikan bermutu adalah pendidikan yang mampu mengembangkan potensi-potensi positif yang terpendam dalam diri siswa. Pendidikan selalu mengupayakan kehidupan manusia ke arah yang lebih baik yang diperlukan untuk kehidupan di masa yang akan datang (Permendikbud, 2013).

Kurikulum 2013 adalah konsep kurikulum terbaru yang ditandatangani dengan meningkatkan karakter dan membangun spiritual, selain meningkatkan pengetahuan yang dipromosikan oleh menteri pendidikan dan budaya di awal 2013 dan sekarang telah direvisi dalam Permendikbud No. 24 tahun 2015 untuk dituangkan dalam pendidikan formal Indonesia (Sufairoh, 2016). Alimuddin menjelaskan bahwa perubahan Kurikulum 2013 berorientasi pada penguatan proses pembelajaran yang memicu siswa mampu berpikir kritis dan memiliki kemampuan seimbang pada aspek sikap, pengetahuan dan keterampilan (Alimuddin, 2014).

Peraturan Menteri Pendidikan dan Kebudayaan Nomor 21 Tahun 2016 tentang Standar Isi menjelaskan kriteria mengenai ruang lingkup materi dan tingkat kompentensi siswa untuk mencapai kompetensi lulusan pada jenjang dan jenis pendidikan tertentu. Standar isi disesuaikan dengan subtansi tujuan pendidikan nasional dalam domain sikap spritual, sikap sosial, pengetahuan, dan keterampilan (Nurmalasari et al., 2016). Selain itu persiapan proses pembelajaran yang dirancang tidak terlepas dari bahan ajar yang digunakan dalam setiap proses pembelajaran.

Peraturan Menteri Pendidikan dan Kebudayaan Nomor 21 BAB III Tahun 2016 menjelaskan tentang tingkat kompetensi dan ruang lingkup materi. Pada kurikulum 2013 telah dijabarkan ruang lingkup materi apa saja yang akan diajarkan pada setiap kelas. Materi pelajaran atau bahan ajar disusun secara sistematis yang digunakan oleh guru dan siswa dalam proses pembelajaran di sekolah. Kurikulum 2013 menekankan pembelajaran dengan pendekatan tematik terpadu. Pembelajaran tematik terpadu merupakan salah satu model pembelajaran terpadu (integrated instruction) yang merupakan suatu sistem pembelajaran yang memungkinkan siswa, baik secara individu maupun kelompok aktif dalam menggali dan menemukan suatu konsep serta prinsip-prinsip keilmuan secara holistik, bermakna, dan otentik (Abidin, 2012)

Pembelajaran tematik terpadu dianggap sebagai salah satu model pengajaran yang paling efektif". Seorang guru harus memiliki kemampuan dalam melaksanakan model pembelajaran tematik terpadu yang benar berdasarkan kurikulum 2013 dengan mempertimbangkan pentingnya penerapan strategi pembelajaran tematik terpadu di sekolah dasar (Desyandri, Purnamasari, \& Yunisrul, 2018; Irawati \& Elmubarok, 2015). 
Pangesti (2012:2) menjelaskan bahawa bahan ajar merupakan the foundation of learning in classroom. Daryanto dan Dwicahyono (2014:171) menjelaskan bahwa bahan ajar adalah seperangkat materi yang disusun secara sistematis baik tertulis maupun tidak sehingga tercipta lingkungan atau suasana yang memungkinkan siswa untuk belajar. Selanjutnya Prastowo (2014:138) menjelaskan bahwa bahan ajar adalah segala bentuk bahan yang digunakan untuk membantu guru atau instruktur dalam melaksanakan proses pembelajaran di kelas.

Bahan ajar yang kurang sesuai dengan kriteria, maka akan timbul berbagai permasalahan dalam proses pembelajaran. Salah satu yang perlu diperhatikan dalam pengembangan bahan ajar adalah bahan ajar yang sesuai dengan tuntutan kurikulum dengan kebutuhan siswa, yakni bahan ajar yang sesuai dengan karakteristik dan lingkungan siswa (Mayarnimar \& Taufina, 2017; Sapitri, Mudjiran, \& Taufina, 2019; Taufina \& Chandra, 2017). Dengan adanya bahan ajar, pembelajaran di dalam kelas akan menjadi lebih terarah dan terstruktur. Bahan ajar juga diberikan materi pembelajaran guru harus memberikan materi pembelajaran yang sejalan dengan kehidupan siswa sendiri (Lestari, Susilo, \& Setyosari, 2017; Prastowo, 2013).

Berdasarkan hasil analisis terhadap buku guru dan buku siswa terlihat bahwa : (1) bahan ajar yang digunakan tidak dirancang oleh guru sesuai dengan kebutuhan dan karakteristik siswa. Hal tersebut karena kurangnya pemahaman guru dalam mengembangkan bahan ajar, ini terlihat bahwa guru lebih mengutamakan bahan ajar yang diberikan pemerintah. (2) Bahan ajar dari pemerintah dijadikan patokan utama bagi guru, sehingga belum merangsang keberanian siswa untuk menceritakan pengalamannya berkaitan dengan materi yang sedang dipelajari. Demirel (Eren, 2017:4) menjelaskan bahwa pengembangan dan penggunaan bahan ajar kadang lebih berguna daripada menggunakan bahan siap pakai. (3) Bahan ajar yang ada belum mampu mengembangkan keberanian dan keterampilan siswa dalam mengemukakan pertanyaan serta pendapat. (4) Pada buku siswa terdapat soalsoal pembelajaran, dimana terlihat bahwa siswa sulit untuk menjawab pertanyaan yang terdapat dalam buku siswa, hal tersebut terjadi karena materi pada bahan ajar sedikit, soal yang diberikan ada yang tidak terdapat pada bahan ajar, sehingga siswa merasa kesulitan dalam menjawab soal (Setiawati, 2016). (5) Bahan ajar belum mendukung kemampuan siswa untuk merumuskan dan mengajukan pertanyaan terkait materi, hal ini dinilai belum sesuai dengan prinsip bahan ajar yang mendorong siswa untuk bertanya (Vianata, 2013).

Berdasarkan pertimbangan tersebut, Berdasarkan paparan tersebut penulis bermaksud melakukan penelitian ini dengan judul "Pengembangan Bahan Ajar Tematik Terpadu dengan Strategi Question Student Have di Kelas IV Sekolah Dasar".

\section{METODE}

Bahan ajar yang dikembangkan Jenis penelitian yang digunakan adalah penelitian pengembangan yang sering disebut Research and Development (R\&D). Sesuai dengan 
permasalahan yang diteliti dan berpedoman pada tujuan penelitian yaitu menghasilkan bahan ajar yang valid. Penelitian dan pengembangan merupakan proses/metode yang digunakan untuk memvalidasi dan mengembangkan produk (Sugiyono, 2013). Penelitian pengembangan adalah suatu penelitian yang digunakan untuk mengembangkan, memvalidasi, menguji keefektifan produk yang digunakan dalam pendidikan. Produk yang dihasilkan dapat berupa bahan ajar, materi belajar, media, soal, dan sistem pengelolaan dalam proses pembelajaran.

\section{Pelaksanaan penelitian dimulai} dengan tahap define. Tahap pendefinisian bertujuan untuk menetapkan dan mendefinisikan syarat-syarat yang dibutuhkan dalam pengembangan bahan ajar. Tahap ini dilakukan dengan menganalisis tujuan dalam batasan materi pelajaran yang dikembangkan. Terdapat tiga langkah yang dilakukan dalam tahap pendefinisian, yaitu:

Analisis Kebutuhan. Analisis kurikulum yang dilakukan dengan menganalisis $\mathrm{KI}, \mathrm{KD}$, dan Indikator pencapaian kompetensi materi yang terdapat dalam silabus yang dikeluarkan olehh BSNP tahun 2013. Dari indikator dirumuskan tujuan pembelajaran yang hendak dicapai oleh siswa.

Beberapa hal yang perlu diperhatikan pada analisis kurikulum ini adalah analisis materi pada tema 4 (Berbagai Pekerjaan) subtema 3 (Pekerjaan Orang Tuaku) kelas IV semester I.

Analisis kebutuhan dilakukan dengan menganalisi buku guru dan buku siswa. Analisis buku guru dilakukan untuk menelaah keterkaitan anatara indikator, tujuan pembelajaran yang hendak dicapai pada kelas IV semester I di dalam tema 4 (Berbagai Pekerjaan) subtema 3 (Pekerjaan Orang Tuaku). Dalam analisis ini dilihat permasalahan yang berkaitan dalam pengembangan bahan ajar termatik terpadu. Analisis buku siswa dilakukan dengan menelaah materi beserta gambar yang terdapat dalam buku siswa. Subjek penelitian adalah buku siswa kelas IV semester I pada tema 4 . Hasil analisis ini dijadikan gambaran untuk mengembangkan bahan ajar tematik terpadu.

$$
\text { Tahap perancangan (design) }
$$

bertujuan untuk merancangan bahan ajar. Bahan ajar dirancang sedemikian rupa sehingga siswa dapat belajar sesuai dengan kemampuan belajarnya masing-masing. Perancangan bahan ajar dilakukan dengan memilih format yang sesuai dengan format penelitian bahan ajar yang baik dan benar dengan memperhatikan kesesuai materi dan kurikulum. Pengembangan bahan ajar disusun sesuai tuntutan $\mathrm{KI}, \mathrm{KD}$, indikator dan tujuan pembelajaran yang mengaju pada komponen yang terdapat pada bahan ajar. Pengembangan bahan ajar ini juga memperhatikan cara penyajian materi pembelajaran tematik terpadu dengan strategi QSH.

Tahap pengembangan (develop) bertujuan untuk menghasilkan bahan ajar yang valid, praktis, dan efektif. Tahap pengembangan meliputi:

1. Validitas isi (content validity), yaitu apakah bahan ajar yang dirancang sesuai dengan pembelajaran tematik.

2. Validitas konstruk (construct validity), yaitu kesesuaian komponen-komponen pengembangan yang sudah ditetapkan. 
480 Pengembangan bahan ajar tematik terpadu dengan strategi question student have di sekolah dasarWeriyanti, Firman, Taufina, Ahmad Zikri

Bahan ajar yang digunakan merupakan bahan ajar yang telah divalidasi oleh validator. Uji praktikalitas bahan ajar dilakukan menggunakan angket dan lembar observasi. Observasi dilakukan oleh dua orang pengamat, yaitu guru dan peneliti sendiri. Observer mengamati keterpakaian bahan ajar dalam proses pembelajaran dan mengisi instrumen observasi yang telah disiapkan. observer mengisi angket keterpakaian bahan ajar fabel. Hasil angket ini dijadikan sebagai dasar untuk melakukan perbaikan terhadap bahan ajar yang dikembangkan. Aspek keterlaksanaan pembelajaran dilihat dari hasil pengisian lembar keterlaksanaan RPP oleh dua orang observer.

Efektivitas dilakukan untuk mengevaluasi bahan ajar telah efektif atau tidaknya. Hal yang dilakukan dengan melihat aktivitas dari pembelajaran.

Tahap Penyebaran (disseminate). Tahap ini merupakan tahap penggunaan bahan ajar yang telah dikembangkan pada subjek lain, misalnya di kelas lain, atau sekolah lain. Tujuannya adalah untuk menguji efektivitas penggunaan bahan ajar tersebut pada subjek yang berbeda. Bahan ajar yang dikatakan efektif jika dapat memberikan hasil yang baik terahadap hasil belajar siswa. Peneliti melakukan penyebaran bahan ajar tematik berbasis QSH dalam skala terbatas yaitu di kelas IV SDN 11 Kampung Pinang.

\section{HASIL DAN PEMBAHASAN}

Validasi ahli isi/materi diperlukan sebagai suatu bentuk evaluasi terhadap isi/materi serta penyajian produk yang telah dikembangkan. Data yang diperoleh berupa data kuantitatif dan kualitatif melalui angket yang diberikan peneliti kepada ahli. Peneliti memberikan angket validasi isi/ materi, dan produk yang dikembangkan. Berdasarkan perhitungan data angket yang diperoleh dari validasi diperoleh sebesar 3,66 dengan kategori sangat valid.

Validasi bahasa. Validasi bahasa diperlukan sebagai evaluasi terhadap bahasa yang digunakan dalam bahan ajar yang sudah dikembangkan. Penggunaan bahasa yang efektif dan komunikatif sangatlah penting dalam sebuah bahan ajar membaca permulaan. Validitas bahasa diberikan kepada ahli berupa angket yang menunjukkan perolehan 3,57 dengan kategori sangat valid.

Validasi aspek penyajian. Validasi penyajian diperlukan sebagai evaluasi terhadap tampilan bahan ajar membaxa permulaan. Data yang diperoleh berupa data kuantitatif dan kualitatif melalui angket yang diberikan peneliti kepada ahli desain pembelajaran Berdasarkan perhitungan data angket yang diperoleh dari validasi ahli desain menunjukkan perolehan sebesar 3,53 dengan kategori sangat valid.

Tabel 1. Hasil Validasi Bahan Ajar

\begin{tabular}{|c|c|c|c|}
\hline No & $\begin{array}{c}\text { Aspek yang } \\
\text { Dinilai }\end{array}$ & $\begin{array}{c}\text { Nilai } \\
\text { Validasi }\end{array}$ & Kategori \\
\hline 1 & $\begin{array}{c}\text { Kelayakan } \\
\text { isi }\end{array}$ & 3,66 & Sangat Valid \\
\hline 2 & Kebahasaan & 3,57 & Sangat Valid \\
\hline 3 & Penyajian & 3,53 & Sangat Valid \\
\hline \multicolumn{2}{|c|}{ Rata-rata } & $\mathbf{3 , 5 6}$ & Sangat Valid \\
\hline
\end{tabular}

Praktikalitas. Salah satu tujuan yang hendak dicapai dari penelitian ini yaitu memperoleh bahan ajar dengan metode QSH di Kelas IV SD yang praktis dan efektif. Setelah dinyatakan praktis dan efektif, kemudian dilakukan dalam kelompok kecil one to one kemudian dilanjutkan dengan small group kemudian dilakukan uji efektifitas bahan ajar.

Tingkat praktikalitas melihat sejauh mana peserta didik dapat menggunakan bahan ajar visual storytelling dengan baik. Pratikalitas yang 
481 Pengembangan bahan ajar tematik terpadu dengan strategi question student have di sekolah dasarWeriyanti, Firman, Taufina, Ahmad Zikri

diamati adalah keterlaksaan RPP, angket respon pendidik dan angket respon peserta didik terhadap pratikalitas bahan ajar. Hasil observasi saat uji coba di lapangan sesuai dengan perencanaan yang telah di buat dengan presentase $90 \%$ dengan kategori sangat praktis.

Efektivitas bahan ajar. Bahan ajar dikatakan efektif apabila memberikan efek atau pengaruh baik terhadap pencapaian tujuan bahan ajar yang dikembangkan. Efektivitas peserta didik dilihat dari hasil belajar peserta didik dalam proses pembelajaran. Hasil analisis data terhadap aktivitas peserta didik ketika proses pembelajaran dengan memperolah hasil $90 \%$.

Validasi diperlukan untuk menguji suatu penelitian. Validitas bahan ajar dan RPP yang telah dikembangkan dikatakan valid apabila memenuhi kriteria tertentu. Menurut Plomp (2012:127) karakteristik dari produk yang dikatakan valid apabila ia merefleksikan jiwa pengetahuan (state of the art knowledge). Hal inilah yang dikatakan dengan validasi isi (content validity). Selanjutnya, komponen-komponen produk tersebut harus konsisten satu sama lain (validitas konstruk). Oleh sebab itu, validasi yang dilakukan terhadap bahan ajar tematik terpadu dan RPP dengan strategi Question Student Have pada penelitian ini menekankan pada validitas isi (content validity) dan validitas konstruksi (construct validity).Validitas isi telah dinyatakan valid oleh validator karena RPP dan bahan ajar tematik terpadu yang dikembangkan telah sesuai dengan materi di kelas IV. Berdasarkan analisis data penelitian validasi dari validator, maka validitas RPP dan bahan ajar tematik terpadu dengan strategi Question Student Have Tema 4 Berbagai Pekerjaan Subtema 3 Pekerjaan Orang Tuaku di kelas IV yang dikembangkan tergolong sangat valid.
Hasil observasi terlaksananya RPP memperlihatkan bahwa pelaksanaan pembelajaran dengan bahan ajar tematik terpadu menggunakan strategi Question Student Have ini sudah berjalan dengan baik. Proses pembelajaran sudah terlaksana sesuia dengan langkah-langkah pembelajaaran dengan strategi Question Student Have. Kegiatan pembelajaran juga telah sesuai dengan waktu yang tersedia. Meskipun pada awalnya terdapat beberapa kegiataan yang tidak terlaksana dengan baik karena keterbatasan waktu dan beberapa siswa kurang terbiasa dengan kegiatan pembelajaran ini. Namun untuk pertemuan berikutnya guru telah mampu memperbaiki kekurangan-kekurangan yang terjadi dan mengarahkan siswa untuk mau mengeluarkan pendapat dan selalu bekerja dengan sungguh-sungguh.

Dalam hal ini, dapat diketahui bahwa bahan ajar yang dikembangkan dapat dengan mudah dilaksanakan oleh guru, artinya bahan ajar yang dikembangkan praktis. Sugiyono (2013) bahwa bahan ajar dapat dikatakan praktis, jika guru dapat menggunakan bahan ajar tersebut untuk melaksanakan pembelajaran secara logis dan berkesinambungan, tanpa banyak masalah. Dengan demikian, bahan ajar tematik terpadu yang telah dikembangkan dapat digunakan sebagai contoh pada sekolah lain yang memerlukannya.

\section{SIMPULAN}

Berdasarkan pengembangan, uji coba, dan penyebaran yang dilakukan peneliti dapat menyimpulkan beberapa hal, sebagai berikut:

1. Bahan ajar menggunakan strategi Question Student Have. Hasil validasi yang dilakukan menunjukkan bahwa bahan ajar yang dikembangkan berada 
pada kategori sangat valid. Hal ini terlihat dari perolehan hasil validasi yang dilakukan validator ahli yaitu 3,57 dan hasil validasi yang dilakukan oleh validator praktisi yaitu 3,74 .

2. Bahan ajar menggunakan strategi Question Student Have yang dihasilkan pada penelitian pengembangan ini telah dapat dinyatakan sangat praktis dari hasil analisis respon guru yaitu dengan rata-rata $90 \%$, dan aspek respon siswa dengan rata-rata $90 \%$.

3. Bahan ajar menggunakan strategi Question Student Have yang dihasilkan pada penelitian pengembangan ini telah dinyatakan efektif dilihat dari hasil aktivitas dan hasil belajar. Aktivitas siswa dapat dilihat dari hasil pengamatan siswa pada saat uji coba dengan rata-rata $81,53 \%$ pada saat penyebaran menjadi $84,66 \%$ terdapat pada kategori sangat aktif. Hasil belajar siswa terdiri dari 2 aspek yaitu pengetahuan dan keterampilan. Pada aspek sikap saat uji coba aspek pengetahuan saat uji coba diperoleh nilai presentase ketuntasan $90 \%$.

\section{DAFTAR PUSTAKA}

Abidin, Y. (2012). Model Penilaian Otentik Dalam Pembelajaran Membaca Pemahaman Beroreintasi Pendidikan Karakter. Jurnal Pendidikan Karakter, 2(2), 164-178.

Alimuddin. (2014). Penilaian dalam kurikulum 2013. In Seminar NAsional Pendidikan Karakter. https://doi.org/10.1038/jes.2014.32

Desyandri, Purnamasari, J., \& Yunisrul. (2018). Peningkatan Pembelajaran Tematik Dengan
Pendekatan Scientific Di Kelas I SDN 15 Ulu Gadut Kota Padang. E-Jurnal Inovasi Pembelajaran SD, 6(1).

Irawati, R. P., \& Elmubarok, Z. (2015). Pengembangan Buku Ajar Bahasa Indonesia Tematik Berkarakter Bagi Siswa Sd Melalui Sastra Anak. Jurnal Pendidikan Karakter, 7(1), 81-96.

Lestari, W. S., Susilo, H., \& Setyosari, P. (2017). Pengembangan Bahan Ajar Tematik Untuk, 1469-1474.

Mayarnimar, \& Taufina. (2017). Validity Analysis of the VARK (Visual, Auditory, Read-Write, and Kinesthetic) Model - Based Basic wReading and Writing Instructional Materials for the 1st Grade Students of Elementary School. In Social Science, Education and Humanities Research (Vol. 118, pp. 870-874). https://doi.org/10.2991/icset-17.2017.141

Nurmalasari, R., Dian, R., Wati, P., Puspitasari, P., Diana, W., \& Dewi, N. K. (2016). Peran Guru Dalam Implementasi Kurikulum 2013. Jurnal Berkala Program Pascasarjana UM Malang. https://doi.org/10.1063/1.3499372

Permendikbud. (2013). Sistem Pendidikan Nasional. Permendikbud No. 20 Tahun 2013. https://doi.org/10.16309/j.cnki.issn.10071776.2003.03.004

Prastowo, A. (2013). Pengembangan bahan ajar tematik. Yogyakarta: Viva Pres.

Sapitri, E., Mudjiran, \& Taufina. (2019). Developing Learning Materials of Narrative Writing Based on the Thinking Ability Improvement Learning Model for Third Grade Student of Elementary School. In Social Science, Education and Humanities Research (Vol. 178, pp. 226-229).

Setiawati, N. (2016). Question Student Have, Sosial Studies Learning Outcomes. Jurnal Cakrawala Pendidikan, XIV(1).

Sufairoh. (2016). Pendekatan Saintifik dan Model Pembelajaran K-13. Bahastra. https://doi.org/10.26555/bahastra.v37i1.5641

Sugiyono. (2013). Metode Penelitian Pendidikan Pendekatan Kuantitaif, Kualitatif, dan R\&D. Metode Penelitian Pendidikan Pendekatan Kuantitaif, Kualitatif, Dan R\&D. https://doi.org/10.1007/s13398-014-0173-7.2

Taufina, \& Chandra. (2017). Developing The Big Questions And Bookmark Organizers (Bqbo) 
483 Pengembangan bahan ajar tematik terpadu dengan strategi question student have di sekolah dasarWeriyanti, Firman, Taufina, Ahmad Zikri

Strategy-Based Literacy Reading Learning Materials In The 4th Grade Of Elementary School. In Social Science, Education and Humanities Research (Vol. 118, pp. 857864). $\quad$ https://doi.org/10.2991/icset17.2017 .139

Vianata, H. (2013). Pengaruh Model Pembelajaran Question Student Have Terhadap Hasi Belajar Ips Sejarah Siswa. Unnes Journal of Public Health, 1(1). 